Plant Tissue Cult. \& Biotech. 19(1): 71-78, 2009 (June)

$\overline{\text { PTC\&B }}$

\title{
In vitro Regeneration through Apical and Axillary Shoot Proliferation of Ficus religiosa L. - A Multi-purpose Woody Medicinal Plant
}

\author{
A.K.M. Sayeed Hassan*, Farhana Afroz, Miskat Ara Akhter Jahan \\ and Rahima Khatun
}

Biological Research Division, BCSIR Laboratories, Dhaka-1205, Bangladesh

Key words: Ficus religiosa, Medicinal plant, Shoot proliferation, Regeneration, Acclimatization

\begin{abstract}
A protocol was established for mass propagation of the valuable medicinal plant Ficus religiosa L. (Moraceae) through in vitro culture using apical and axillary buds of young sprouts from selected plants. Best shoot induction was observed on MS basal medium supplemented with $0.5 \mathrm{mg} / \mathrm{l} \mathrm{BAP}+0.1 \mathrm{mg} / \mathrm{l} \mathrm{IAA}$, in which 78 per cent of the explants produced 16 shoots per culture. Repeated subcultures in the same medium, resulted rapid shoot multiplication with 24 shoots per culture. In vitro raised shoots rooted on half strength MS supplemented with $2.0 \mathrm{mg} / \mathrm{l} \mathrm{IBA}+$ $0.1 \mathrm{mg} / \mathrm{l} \mathrm{NAA}$. For acclimatization and transplantation, the plantlets in the rooting culture tubes were kept in normal room temperature for seven days before transplanting in pots where plantlets were reared for three weeks. The survival rate of regenerated plantlets was 85 per cent.
\end{abstract}

\section{Introduction}

Ficus religiosa L. commonly known as 'Ashathwa' belongs to Moraceae is a large, widely branched tree with leathery, heart-shaped, long-tipped leaves on long slender petioles and purple fruits growing in pairs, grows both wild and planted throughout the Bangladesh (Ghani 1998). The tree is found wild or cultivated nearly throughout India and is held sacred by Hindus and Buddhists. It is planted as an avenue or roadside tree. It grows fast and can be raised from seeds. It can also be propagated by cuttings, but these do not establish so well as those of Ficus bengalensis. The fruits and tender leaf buds are occasionally eaten in times of scarcity. The fruits are eagerly devoured by birds. Extract of bark is antibacterial, astringent, relaxant and spasmolytic on smooth muscles and is used in diarrhoea, dysentery, gonorrhea, scabies and ulcers (Ghani 1998). An aqueous extract of the bark shows anti-bacterial activity against Staphylococcus aureus and Escherichia coli.

${ }^{*}$ Corresponding author. 
Leaves and young shoots are purgative and used in skin diseases. Seeds are cooling, alterative and laxative; taken for three days during menses, sterilizes women for long time. Ethanolic extract of bark is antiprotozoal, anthelmintic and antiviral (The Wealth of India 1956).

In recent years, there has been an increased interest in in vitro culture techniques which offer a viable tool for mass multiplication and germplasm conservation of rare, endangered and threatened medicinal plants (Ajithkumar and Seeni 1998, Prakash et al. 1999). It is important to develop an efficient micropropagation technique for Ficus religiosa to rapidly disseminate superior clones once they are identified. There have been a few reports to date on micropropagation of Ficus religiosa using shoot tips and nodal explants. However, in Bangladesh, there is no report on the establishment of a micropropagation protocol for Ficus religiosa. The present study was, therefore undertaken to develop a protocol for mass clonal propagation of this important medicinal plant through in vitro culture.

\section{Materials and Methods}

The experiment was conducted at Biological Research Division in BCSIR Laboratories, Dhaka. Healthy and profusely growing vine of Ficus religiosa L. was collected from BCSIR campus, Dhaka and used as the source of explants. Shoot tips and nodal explants with a single axillary bud were used for this purpose. The explants were washed thoroughly under running tap water, pre-soaked in liquid detergent for about $30 \mathrm{~min}$, wiped with cotton and dipped in $70 \%(\mathrm{v} / \mathrm{v})$ ethanol for $1 \mathrm{~min}$. They were then surface sterilized with $0.1 \%(\mathrm{w} / \mathrm{v})$ mercuric chloride for $5 \mathrm{~min}$, followed by five rinses with sterile distilled water in front of a laminar air flow cabinet. The surface sterilized explants were cut into $1-1.5 \mathrm{~cm}$ length containing a single node with an axillary bud or a shoot tip with an apical bud. The explants were placed vertically on the culture medium. The new shoots induced from the in vitro cultures were further used as an explants for adventitious shoot regeneration.

MS basal medium was used for shoot proliferation and adventitious shoot regeneration and half strength of MS was used for in vitro rooting. All media were supplemented with $30 \mathrm{~g} / \mathrm{l}$ sucrose, $7 \mathrm{~g} / \mathrm{l}$ agar (Difco) and dispensed into $15 \times 150$ $\mathrm{mm}$ culture tubes and $250 \mathrm{ml}$ conical flasks. The $\mathrm{pH}$ of the media was adjusted to 5.8 before autoclaving at $121^{\circ} \mathrm{C}$ for $20 \mathrm{~min}$. The cultures were incubated for a $16 \mathrm{hr}$ photoperiod at $24 \pm 2^{\circ} \mathrm{C}$ under a fluorescent light.

Shoot proliferation from shoot tips and nodal explants was obtained in two separate sets of experiments. In the first experiment $0-2.5 \mathrm{mg} / \mathrm{l} \mathrm{BAP}$ and $0-2.5$ $\mathrm{mg} / \mathrm{l} \mathrm{Kn}$ were supplied into MS to select the best cytokinin for the response of shoot induction. In the second set, combination of BAP - NAA (0 - $2.5 \mathrm{mg} / \mathrm{l})$ and 
BA - IAA (0 - $2.5 \mathrm{mg} / \mathrm{l})$ were assessed for shoot multiplication. Number of new shoot proliferation in each culture was recorded after every week of inoculation.

For in vitro rooting, individual shoots $(3-5 \mathrm{~cm})$ were excised from the proliferated shoot cultures and implanted into half strength of MS with different concentrations and combinations of NAA, IBA and IAA.

The rooted plants were taken out from the culture tubes, washed to remove agar gel adhered to the roots and transplanted to plastic pots with soil and compost $(1: 1)$ for hardening. The plantlets were kept in a polychamber at 80 per cent relative humidity, $32 \pm 2{ }^{\circ} \mathrm{C}$ under a $12 \mathrm{hr}$ photoperiod for acclimazation. Established plants were transplanted in earthen pots under natural conditions and the survival rate was recorded.

\section{Results and Discussion}

Shoot tips and nodal explants of Ficus religiosa L. were cultured on MS supplemented with various concentration of BAP alone and in combination with NAA or IAA for multiple shoot regeneration. Among the three different media and growth regulators tested, MS was found to support a better response for multiple shoot regeneration than B5 and WPM media (Fig. 1). MS was found to be more effective than other for Apiaceae members (Suchitra et al. 1999, Sakia et al. 2001, Shashikala et al. 2005). In WPM and B5 media smaller number of vitrified shoots were produced.

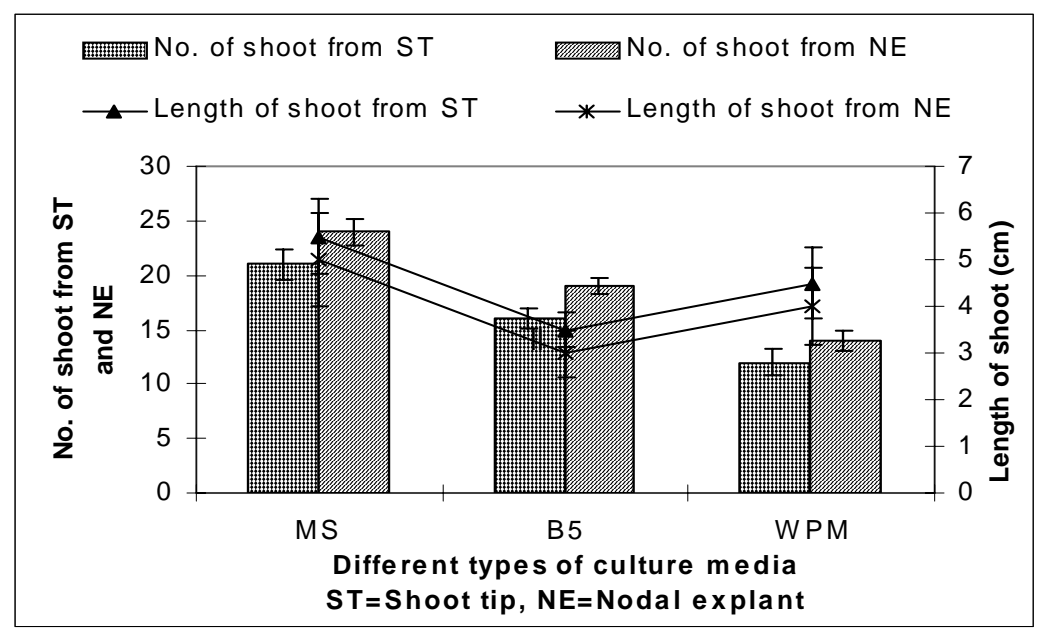

Fig. 1. Effect of different types of culture media on number of shoot per culture and length of shoots of Ficus religiosa.

The inoculated explants (shoot tips and nodal explants) were found to be swollen and they produced three to four shoots within three-four weeks (Fig. 2a, b) on MS containing BAP alone but best microshoot formation was observed 
(24.2) from nodal explant (Fig. 2c ) and shoot tip explants (18.8) in MS with 0.5 $\mathrm{mg} / \mathrm{l} \mathrm{BAP}+0.1 \mathrm{mg} / \mathrm{l} \mathrm{IAA}$ (Table 1). Repeated subculturing of the microshoots in the same medium resulted profuse shoot stimulation and elongation (Fig. 2d). Combination of BAP with NAA or BAP alone was not found suitable than BAP with IAA for shoot induction (Table 1). Deshpande et al. (1998) reported that dormant axillary buds of nodal explants collected from a mature tree of Ficus religiosa sprouted on MS supplemented with $5.0 \mathrm{mg} / \mathrm{l} \mathrm{BAP}$ and $0.2 \mathrm{mg} / \mathrm{l} \mathrm{IBA}$ within four days and multiple shoots were obtained when these explants were

Table 1. Effect of BAP, NAA and IAA in MS on morphogenic response of $F$. religiosa from shoot tips and nodal segments.

\begin{tabular}{|c|c|c|c|c|c|c|}
\hline \multicolumn{3}{|c|}{$\begin{array}{l}\text { Growth regulators } \\
\qquad(\mathrm{mg} / \mathrm{l})\end{array}$} & \multirow{2}{*}{$\begin{array}{l}\text { Shoot } \\
\begin{array}{c}\text { \% of explants } \\
\text { forming } \\
\text { shoots }\end{array}\end{array}$} & \multirow{2}{*}{$\begin{array}{c}\text { tips } \\
\text { Mean No. } \\
\text { of shoot/ } \\
\text { explant }\end{array}$} & \multicolumn{2}{|c|}{$\begin{array}{c}\text { Nodal } \\
\text { segments }\end{array}$} \\
\hline BAP & NAA & IAA & & & $\begin{array}{c}\% \text { of explants } \\
\text { forming } \\
\text { shoots }\end{array}$ & $\begin{array}{c}\text { Mean No. } \\
\text { of shoot/ } \\
\text { explant }\end{array}$ \\
\hline Control & & & - & - & - & - \\
\hline 0.5 & & & $34.8 \pm 2.58$ & $11.2 \pm 0.37$ & $41.2 \pm 2.47$ & $12.6 \pm 0.35$ \\
\hline 1.0 & & & $28.2 \pm 1.66$ & $10.8 \pm 0.37$ & $32.2 \pm 0.66$ & $12.4 \pm 0.45$ \\
\hline 1.5 & & & $22.2 \pm 1.96$ & $9.4 \pm 0.50$ & $33.6 \pm 1.84$ & $11.4 \pm 0.82$ \\
\hline 2.0 & & & $21.0 \pm 1.14$ & $8.6 \pm 0.81$ & $43.6 \pm 0.51$ & $10.6 \pm 0.77$ \\
\hline 0.5 & 0.1 & & $63.4 \pm 1.57$ & $14.6 \pm 0.50$ & $71.4 \pm 2.38$ & $17.6 \pm 1.08$ \\
\hline 1.0 & 0.2 & & $57.6 \pm 2.16$ & $13.0 \pm 1.30$ & $68.6 \pm 1.70$ & $15.4 \pm 0.92$ \\
\hline 1.5 & 0.5 & & $48.8 \pm 1.77$ & $11.4 \pm 1.36$ & $56.8 \pm 2.14$ & $14.8 \pm 0.99$ \\
\hline 2.0 & 0.5 & & $42.6 \pm 0.87$ & $11.0 \pm 1.14$ & $47.6 \pm 2.10$ & $13.2 \pm 0.59$ \\
\hline 0.5 & & 0.1 & $72.4 \pm 2.89$ & $18.8 \pm 1.39$ & $88.2 \pm 2.80$ & $24.2 \pm 1.24$ \\
\hline 1.0 & & 0.2 & $61.4 \pm 2.87$ & $14.4 \pm 0.92$ & $67.6 \pm 2.16$ & $15.4 \pm 0.45$ \\
\hline 1.5 & & 0.5 & $16.2 \pm 0.86$ & $11.2 \pm 0.86$ & $18.4 \pm 0.93$ & $11.2 \pm 0.76$ \\
\hline 2.0 & & 0.5 & $26.6 \pm 1.66$ & $10.4 \pm 0.72$ & $32.6 \pm 1.63$ & $10.4 \pm 0.45$ \\
\hline
\end{tabular}

Results are mean \pm SE of three experiments with 15 replications.

transferred to MS containing $1.5 \mathrm{mg} / \mathrm{l} \mathrm{BAP}$ and $1.5 \mathrm{mg} / \mathrm{l}$ ADS. These multiple shoots were allowed to elongate to $4-5 \mathrm{~cm}$ by maintaining them on MS containing $2.0 \mathrm{mg} / \mathrm{l} \mathrm{BAP}$ with $0.5 \mathrm{mg} / \mathrm{l} \mathrm{NAA}$ and $0.3 \%$ activated charcoal. A similar phenomenon was observed in different medicinal plants by other researchers (Gawde and Paratkar 2004, Rahman et al. 2004, Munshi et al. 2004, Rahman et al. 2006, Baskaran and Jayabalan 2005, Sinha et al. 2005, Husain and Anis 2006, Han et al. 2007, Usha et al. 2007, Hassan 2008, Afroz et al. 2008).

A little more than 80 per cent regenerated shoots rooted (Fig. 2e) when cultured individually on root induction medium consisting of half-strength MS with $2.0 \mathrm{mg} / \mathrm{l} \mathrm{IBA}+0.1 \mathrm{mg} / \mathrm{l}$ NAA (Table 2). Use of auxins singly or in combination for rooting was also reported by different authors (Sahoo and Chand 1998, Ajithkumar and Seeni 1998, Sivakumar and Krishnamurthy 2000, 
Rai 2002, Hassan and Roy 2004, Sinha et al. 2005, Rahman et al. 2006, Baksha et al. 2007, Hassan et al. 2008).
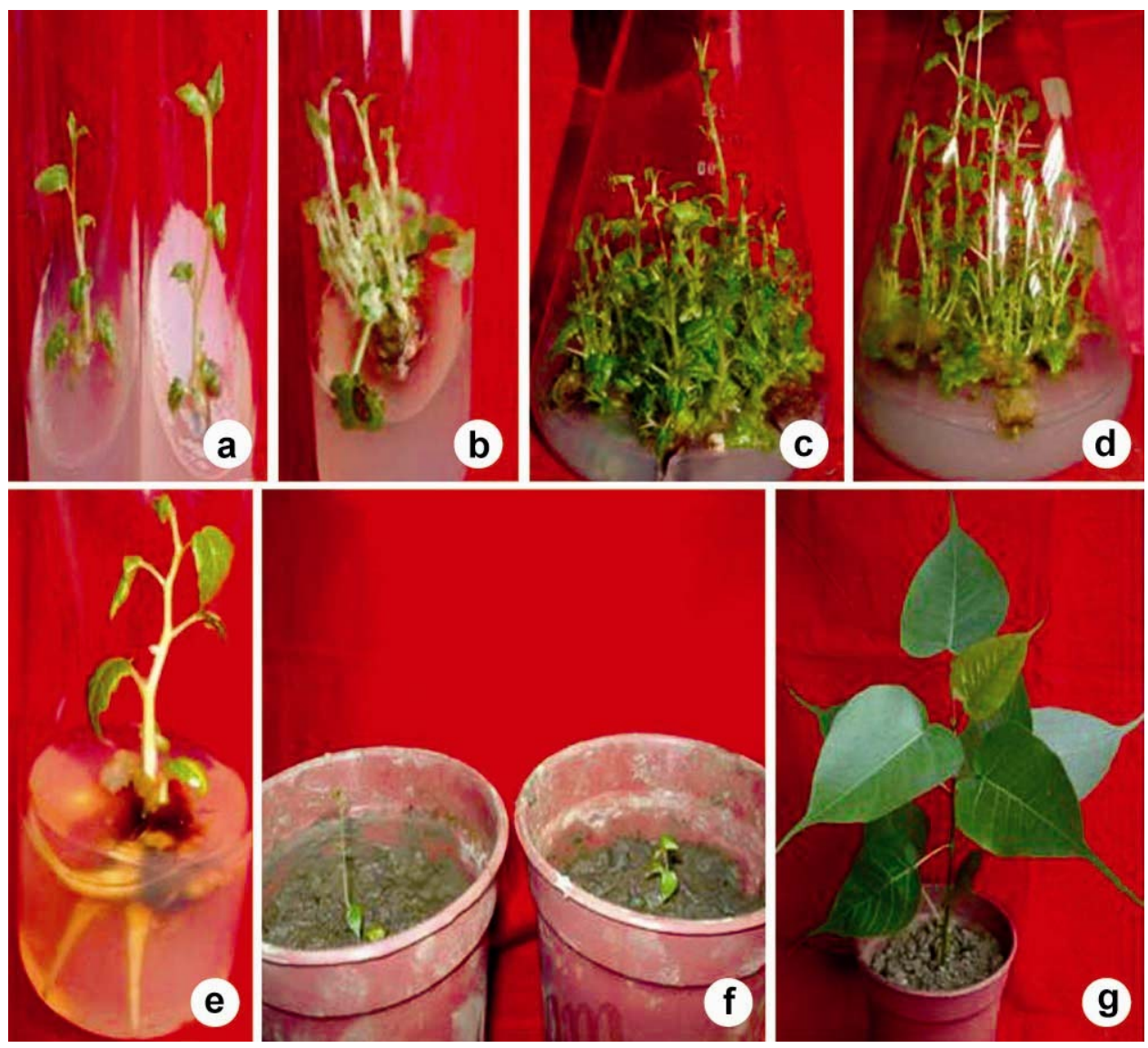

Fig. 2. In vitro regeneration of Ficus religiosa from shoot tip and nodal explants. a. Induction of shoots in four weeks of culture. b. Induction of shoots in four weeks of culture from nodal explants. c. Development and multiplication of shoots after eight weeks of culture. d. Development and multiplication of shoots after 12 weeks of culture. e. Rooting of in vitro regenerated shoots in three weeks. f. Acclimatized regenerated plants of seven days old. g. Acclimatized regenerated plants of six months old.

After four weeks the rooted shoots were transferred to pots. None of the plantlets survived when they were directly transferred from rooting medium to the pot under natural conditions. About 85 per cent of the transplanted plants of Ficus religiosa survived if the plants in the rooting culture tubes were kept in normal room temperature for seven days before transplantation in pots and reared for three weeks. The plantlets were reared under semi-controlled temperature $\left(30 \pm 2^{\circ} \mathrm{C}\right)$ and light (2000 lux) in a chamber with 80 per cent humidity. During this period of acclimation shoots elongated, leaves expanded and turned deep green and healthier (Fig 2f, g). 
After three weeks, plants were transferred to an open place, 85 - 90 per cent plants survived. The technique described here appears to be readily adoptable for large scale clonal propagation and plantation for sustainable use in the industry. Moreover, by standardizing the protocols for clonal propagation of selected elite plants, it is possible to achieve a tenfold increase in the products per

Table 2. Effect IAA, IBA and NAA on root induction in regenerated shoots of F. religiosa L. on half strength MS.

\begin{tabular}{|c|c|c|c|c|}
\hline \multicolumn{3}{|c|}{ Growth regulators (mg/l) } & \multirow{2}{*}{$\begin{array}{c}\% \text { of shoots producing } \\
\text { roots }( \pm S E)\end{array}$} & \multirow{2}{*}{$\begin{array}{l}\text { No. of roots/shoot } \\
\qquad( \pm S E)\end{array}$} \\
\hline IAA & IBA & NAA & & \\
\hline 0.5 & & & - & - \\
\hline 1.0 & & & - & - \\
\hline 1.5 & & & - & - \\
\hline \multirow[t]{8}{*}{2.0} & & & - & - \\
\hline & 0.5 & & $49.6 \pm 1.17$ & $3.2 \pm 0.20$ \\
\hline & 1.0 & & $54.8 \pm 0.86$ & $3.4 \pm 0.24$ \\
\hline & 1.5 & & $67.2 \pm 1.07$ & $3.6 \pm 0.40$ \\
\hline & 2.0 & & $74.4 \pm 0.75$ & $3.8 \pm 0.37$ \\
\hline & & 0.5 & $24.4 \pm 0.51$ & $2.2 \pm 0.20$ \\
\hline & & 1.0 & $28.2 \pm 1.56$ & $2.4 \pm 0.24$ \\
\hline & & 2.0 & $33.8 \pm 0.86$ & $2.6 \pm 0.40$ \\
\hline 1.0 & & 1.0 & $37.4 \pm 1.60$ & $2.4 \pm 0.40$ \\
\hline \multirow[t]{7}{*}{2.0} & & 2.0 & $24.4 \pm 0.51$ & $2.2 \pm 0.20$ \\
\hline & 1.0 & 0.1 & $52.4 \pm 0.75$ & $3.4 \pm 0.514$ \\
\hline & 1.0 & 0.5 & $49.2 \pm 1.53$ & $3.2 \pm 0.37$ \\
\hline & 1.0 & 1.0 & $37.4 \pm 1.60$ & $2.4 \pm 0.40$ \\
\hline & 2.0 & 0.1 & $81.4 \pm 0.87$ & $5.8 \pm 0.66$ \\
\hline & 2.0 & 0.5 & $72.4 \pm 0.98$ & $4.8 \pm 0.73$ \\
\hline & 2.0 & 2.0 & $68.8 \pm 0.66$ & $4.4 \pm 0.51$ \\
\hline 1.0 & 1.0 & 1.0 & $46.6 \pm 0.68$ & $3.0 \pm 0.32$ \\
\hline 2.0 & 2.0 & 2.0 & $64.2 \pm 1.11$ & $3.6 \pm 0.51$ \\
\hline
\end{tabular}

Data were recorded after four weeks of culture. Results are mean \pm SE of 15 replications.

unit area of cultivation (Hassan and Roy 2005). Clonally propagated plants would also have identical phytochemical profiles (Roja and Heble 1993). Likewise it could be possible to propagate important medicinal plants for cultivation and sustainable use and consequently to conserve them from their extinction. 


\section{Acknowledgement}

This study is a part of the Post Doctoral research of the first author (AKMSH). The authors are indebted to Professor Dr. Shyamal K. Roy, Department of Botany, Jahangirnagar University, Savar, Dhaka. Grateful acknowledgement is also due to the Professor Dr. Choudhury Mahmood Hasan, Ex. Chairman, BCSIR, Dhaka and Professor Elias Khan, Principal, Savar College, Savar, Dhaka for their kind permission, critical suggestions and encouragement during the period of work.

\section{References}

Afroz F, Hassan AKMS, Bari LS, Munshi JL, Jahan MAA and Khatun R (2008) In vitro regeneration of Vitex negundo L., a woody valuable medicinal plant through high frequency axillary shoot proliferation.. Bangladesh J. Ind. Res. 43(3): 345-352.

Ajithkumar D and Seeni S (1998) Rapid Clonal Multiplication through in vitro Axillary Shoot Proliferation of Aegle marmelos (L) Corr., a Medicinal Tree. Plant Cell Rep. 17: 422-426.

The Wealth of India: Raw Materials (1956) CSIR, New Delhi, India. 4: 38-39.

Baksha R, Jahan MAA, Khatun $\mathbf{R}$ and Munshi JL (2007) In vitro rapid clonal propagation of Rauvolfia serpentina (Linn.) Benth. Bangladesh J. Ind. Res. 42(1): 37-44.

Baskaran P and Jayabalan N (2005) An efficient micropropagation system for Eclipta alba a valuable medicinal herb. In Vitro Cell. Dev. Biol. Plant. 41: 532-539.

Deshpande SR, Josekutty PC and Prathapasenan G (1998) Plant regeneration from axillary buds of a mature tree of Ficus religiosa. Plant Cell Reports 17(6-7): 571-573.

Ghani A (1998) Medicinal Plants of Bangladesh with Chemical Constituents and Uses, Asiatic Society of Bangladesh, Dhaka. pp. 236.

Gawde AJ and Paratkar GT (2004) Micropropagation of Eclipta alba Hassk - An approach to shorten the protocol. Indian Journal of Biotech. 3(1) : 128-1323.

Hassan AKMS and Roy SK (2004) Micropropagation of Smilax zeylanica L., a perennial climbing medicinal shrub, through axillary shoot proliferation. Bangladesh J. Life Sci. 16(1): 33-39.

Hassan AKM and Roy SK (2005) Micropropagation of Gloriosa superba L. through high frequency shoot proliferation. Plant Tissue Cult. and Biotech. 15(1): 67-74.

Hassan AKMS (2008) In vitro regeneration of a woody medicinal plant, Pterocarpus santalinus Linn. f., through apical and axillary shoot proliferation. Bangladesh J. Life Sci. 20(1): 2936.

Hassan AKMS, Afroz F, Bari LS, Munshi JL, Jahan MAA and Khatun R (2008) Micropropagation of Eclipta alba (Linn.) Hassk - a valuable medicinal herb. Bangladesh J. Ind. Res. 43(2): 215-222.

Han L, Guo S and Chang M (2007) Tissue culture of Eclipta prostrata L. Chinese Pharmaceutical Journal 42(2) : 94-98.

Husain MK and Anis M (2006) Rapid in vitro propagation of Eclipta alba (L.) Hassk. through high frequency axillary shoot proliferation. Acta Physiologiae Plantarum. 28(4) : 325-330. 
Munshi MK, Hakim L, Islam MR and Ahmed G (2004) In vitro clonal propagation of banyan (Ficus benghalensis L.) through axillary bud culture. International Journal of Agriculture and Biology 6(2): 321-323.

Prakash E, Sha Valli Khan PS, Sairam Reddy P and Rao KR (1999) Regeneration of plants from seed-derived callus of Hybanthus enneaspermus L. Muell., a rare ethnobotanical herb. Plant Cell Rep. 18: 873-878.

Rahman MM, Amin MN and Hossain MF (2004) In vitro propagation of banyan tree (Ficus benghalensis L.) - a multipurpose and Keystone species of Bangladesh. Plant Tissue Cult. and Biotech. 14(2): 135-142.

Rahman SMR, Afroz F, Sultana K, Sen PK and Ali MR (2006) Effect of growth regulators and state of medium on micropropagation of Adhatoda vasica (Nees.) Khulna University Studies, Special Issue ( $1^{\text {st }}$ Research Cell Conference): 55-59.

Rai VR (2002) Rapid clonal propagation of Nothapodytes foetida (Weight) Sleumer - a threatened medicinal tree. In Vitro Cell Dev. Biol.Plant, 38: 347-351.

Roja G and Heble MR (1993) The quinoline alkaloids camptothecin and 9-methoxy camptothecine from tissue culture and mature trees of Nothapodytes foetida. Phytochemistry $36: 65-66$.

Sahoo Y and Chand PK (1998) Micropropagation of Vitex nigundo L., a woody aromatic medicinal shrub, through high frequency axillary shoot proliferation. Plant Cell Rep. 18: 301-307.

Sakia FR, Baruah CC, Deka AC and Kalita MC (2001) Micropropagation of Hydrocotyle rotundifolia an indigenous medicinal plant of north east India. J. Med. Arom. Pl. Sci. 23: 291-193.

Shashikala CM, Shashidharan S and Rajashekharan PE (2005) In vitro regeneration of Centella asiatica L. Plant Cell Biotech. Mol. Biol. 6: 53-56

Sinha S, Hassan AKMS and Roy SK (2005) Regeneration of Hydnocarpus kurzi (King) Warb.- a red-listed medicinal plants. Plant Tissue Culture \& Biotechnology 15(2): 113119.

Sivakumar G and Krishnamurthy KV (2000) Micropropagation of Gloriosa superba L.- an endangered species of Asia and Africa. Curr. Sci. 78(1): 30-32.

Suchitra B, Zera M and Kumar S (1999) In vitro multiplication of Centella asiatica L. Curr. Sci. 76: 147-158.

Usha PK, Benjamin S, Mohanan KV and Raghu AV (2007) An efficient micropropagation system for Vitex negundo L., an important woody aromatic medicinal plant, through shoot tip culture. Res. J. Bot. 2(2): 102-107. 